\title{
NATURAL VEGETATION DYNAMICS AROUND THE IRATI NATIONAL FOREST, BRAZIL, IN RESPONSE TO ENVIRONMENTAL POLICIES AND AGRIGULTURAL EXPANSION FROM 1992 TO 2017
}

\author{
David HC${ }^{1,}$ *, Fernandes APD ${ }^{1}$, Barbosa ES $^{1} \&$ Neto RPM ${ }^{2}$ \\ ${ }^{1}$ Rural Federal University of Amazonia, Capitão Poço, PO Box 68650-000, Brazil \\ ${ }^{2}$ Department of Cartography, State University of São Paulo, PO Box 19060-900, Presidente Prudente, Brazil \\ *hassancamil@gmail.com
}

Submitted November 2018; accepted July 2019

\begin{abstract}
The aim of this research was to relate natural vegetation dynamics to environmental policies and agricultural pressure surrounding the Irati National Forest (INF), in the state of Parana, Brazil. We mapped landuses and detected their changes over a period of 25 years (1992 to 2017), emphasising gains and losses of natural vegetation to other uses. Employing a pixel-based approach, Landsat-5 TM and Landsat-8 OLI data were used to classify landuse surrounding the INF. We reviewed records of agricultural expansion and environmental policies in Parana to explain losses and gains in vegetation cover detected in the landuse change analysis. During the study period the area surrounding the INF gained $\sim 10,000$ ha of natural vegetation cover regenerated from areas formerly under crop or pasture cover and planted forests, but lost $\sim 20,000$ ha, largely to agricultural expansion, likely for soybeans. We discuss environmental policies, particularly the Ecological ICMS (a Brazilian ecological fiscal incentive paid to counties that shelter protected areas) as the most important reason for the vegetation regeneration and nature conservation.
\end{abstract}

Keywords: Landuse change, deforestation, agricultural expansion, natural regeneration, Ecological ICMS

\section{INTRODUCTION}

Parana, a state of Brazil, holds some of the most extensive remaining tracts of the Atlantic Forest biome. This biome is dominated by mixed rainforest with a predominant presence of native Araucaria forests. In Parana, large areas of these forests are designated conservation units (CUs) of high ecological importance, e.g. the Irati National Forest (INF, 3800 ha) established in 1968, Araucarias Biological Reserve (ABR, 14,930 ha) established in 1983 and representing Parana's most important reserve of Araucaria angustifolia, and the Ecological Station of Fernandes Pinheiro (ESF, 532 ha) established in 2001.

Deforestation was, and still is, a threat to forests of Parana. Among the states belonging to the Atlantic Forest biome, Parana holds one of the highest historical rates of deforestation (SOSMA 2017). Several national environmental policies have been put in place to protect the forests, e.g. State Law 10.066/92, to establish the Environmental Institute of Parana and
Secretary of State for Environment, both related to inspections and regulations of environmental issues; Law 12651/2012 (The Native Vegetation Protection Law), to protect native vegetation by way of permanent preservation areas; Law 11.428/2006 (The Atlantic Rainforest Law), to preserve remnants of Atlantic forest by prohibiting large-scale logging (Crouzeilles et al. 2019).

In Parana, the policy ICMS-E (Ecological ICMS, or Imposto sobre Circulação de Mercadorias e Serviços) was implemented in 1991 to encourage conservation of CUs and their surrounding forests. This public policy aims to transfer financial resources to counties with CUs, watershed areas and other protected areas (Paulo \& Camões 2018, Sauquet et al. 2014). With this policy in place rewarding local governments for their commitment to protecting forest and biological resources, Parana's public and private forest areas increased by more than 1 mil ha in the first eight years of introduction (Ring et al. 
2010). In 2017 alone, the three CUs (INF, ABR and ESF) contributed 2.5 mil Brazilian reals ( USD 601,500$)$ to their respectively counties.

While the INF has been the focus of extensive research examining its ecological role in maintaining local biodiversity (Rode et al. 2010, 2011), landuse surrounding the INF has been less studied. This NF is surrounded by a $3-\mathrm{km}$ radius buffer zone as required for CUs with no previously defined buffer zones (CUs with defined Forest Management Plans are each required to have a $10-\mathrm{km}$ radius buffer zone). The purpose of buffer zones is to mitigate impacts of external anthropogenic activities, e.g. noise, pollution and invasive species introductions, on the CUs. Buffer zones also help prevent fires that occur due to landscape fragmentation (Numata et al. 2017). Forest fragmentation leads to ecological changes in the resultant smaller, more isolated, edge effect-prone forest fragments that are often surrounded by a mosaic of modified habitats (Laurance \& Vasconcelos 2009). Anthropogenic activities around the INF increased wildfires by $\sim 8 \%$ (Tetto et al. 2012), a percentage rise that could be prevented with better management of its buffer zone. Herbicide applications on crops close to the buffer zones and incursions of cattle also damage buffer zone vegetation.

Here, we reviewed forest policies such as the ICMS-E, agricultural expansion and the course of forest conservation and degradation in Parana. Our aim was to evaluate natural vegetation dynamics for the area surrounding the INF, in relation to environmental policies and agricultural pressure. Landuse change was assessed over a period of 25 years (19922017), emphasising gains and losses of natural vegetation to other landuses.

\section{MATERIALS AND METHODS}

\section{Study area}

The study area encompassed a large rectangularshaped four-county-wide area surrounding the INF, but excluding the NF itself, which has been extensively studied (Figure 1). Included in the study area were two CUs: ABR and ESF. The delimited study area would enable evaluation of landuse changes for both these CUs, and also forest fragments within and beyond the buffer zone of the INF. The area of and beyond the $3 \mathrm{~km}$-radius buffer zone was 14,612 and 102,809 ha respectively, for a total of 117,421 ha.

The climate of the region is humid subtropical with hot to moderately hot summers (Cfa to $\mathrm{Cfb}$ respectively, Köeppen) and mean temperature in the warmest month exceeding $22^{\circ} \mathrm{C}$. Annual rainfall is between 1300 and $1600 \mathrm{~mm}$ and mean annual temperature is $17.7^{\circ} \mathrm{C}$ (Alvares et al.

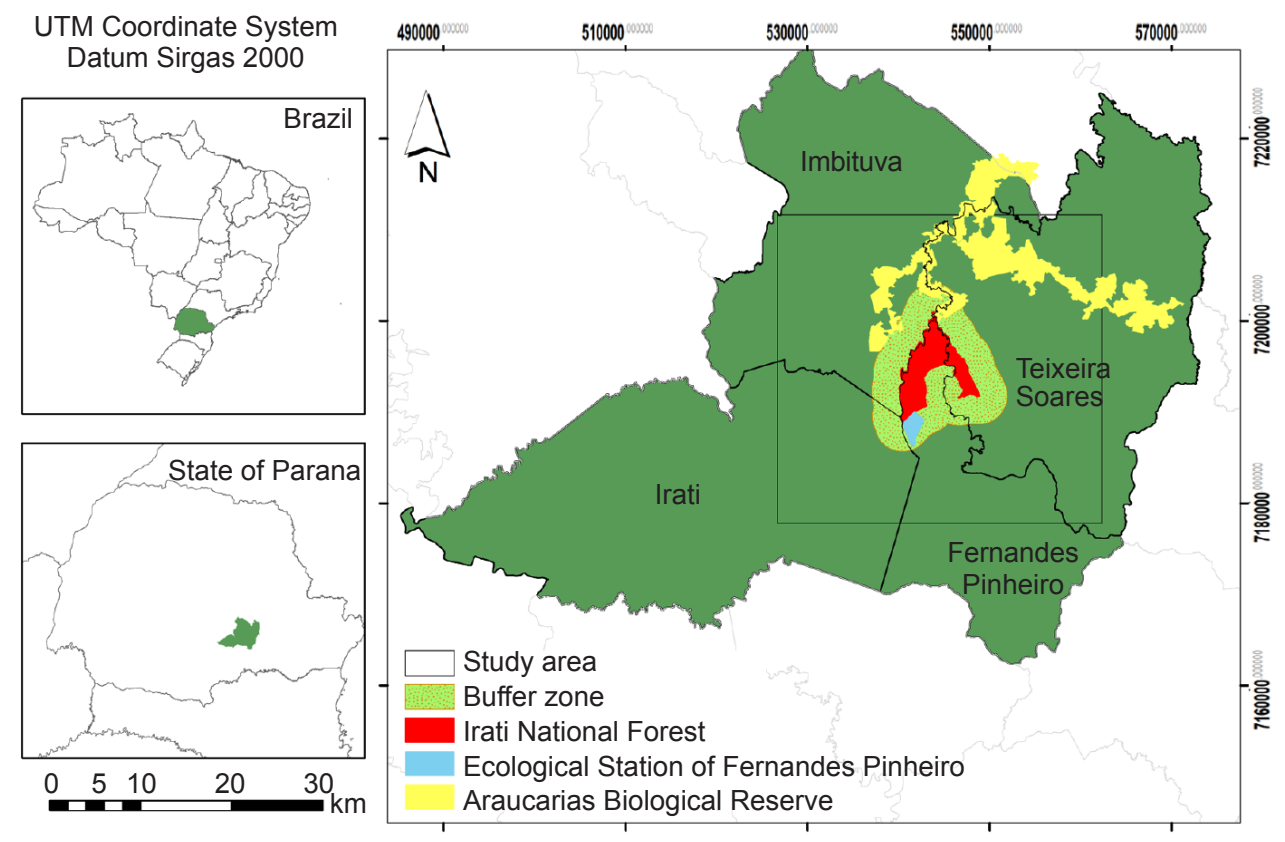

Figure 1 Location of the Irati National Forest delimited by Fernandes Pinheiro, Teixeira Soares, Imbituva and Irati municipalities (state of Parana, Brazil) 
2014). The study area falls within $400-1400 \mathrm{~m}$ altitude.

The predominant local landuse classes were natural vegetation, planted forests, pastures and crop plantations.

\section{Landuse classification}

\section{Image acquisition and pre-processing}

The Landsat scene locations were selected from Path 224 Row 74, based on the Landsat worldwide reference system. Satellite imagery was acquired from the Earth Explorer page (http:/ / earthexplorer.usgs.gov) of the United States Geological Survey website. The images used were Landsat 5 Thematic Mapper (TM sensor) of 19 July 1992 and Landsat 8 Operational Land Imager (OLI sensor) of 13 January 2017, both dates had cloud cover $<1 \%$. The study area has high cloud cover year-round, thus, image acquisition prioritised dates with the lowest cloud cover.

All data was re-projected into the Universal Transverse Mercator Projection 22 South spindle and SIRGAS 2000 Datum. Next, an atmospheric correction was performed through the Fast Line-of-sight Atmospheric Analysis of Spectral Hypercubes (FLAASH) algorithm, available with the ENVI ${ }^{\circledR} 5.3$ software (2015). The FLAASH algorithm is based on the radioactive transfer model Moderate Spectral Resolution Atmospheric Transmittance Algorithm, described in Ponzoni et al. (2012). The algorithm executes the process of atmospheric correction with values of radiation, so it was necessary to transform Digital Number from images to the physical variable radiance. This atmospheric correction yields a corrected image with surface reflectance necessary for studies involving biophysical parameters of vegetation and multitemporal analyses. Lastly, the images were clipped through a vector file in order to delimit the study area.

\section{Landuse and land cover classes}

The classes analysed in this study were (1) early- and mid- to late-successional natural vegetation, (2) planted forest, (3) tillage and pasture and (4) uncovered soil (Table 1). The collection of pixel samples of natural vegetation followed the criteria established by Resolution No. 2 (CONAMA 1994), a national standard characterising types and successional stages of natural vegetation and forests. To reduce misclassification, three classes unrelated to landuse were additionally created: water, cloud and shade.

While the classification included seven classes, evaluation was carried out only for classes related to landuse. For each landuse class, 30 to 40 initial samples containing at most 100 pixels were collected. For the smaller water, cloud and shadow classes, 10 samples were collected for each class. Initial classifications were performed with these samples. Based on the preliminary classification results, some initial samples were excluded and others added, until sample classification achieved $100 \%$ accuracy.

\section{Classification and post-classification of landuse}

We applied the pixel-based classification with the maximum likelihood (ML) algorithm, using ENVI® 4.7 software (2015). Assuming the statistics for each class in each image band are normally distributed, ML classification calculates the probability of a given pixel belonging to a specific class (Richards 1999). The highest probability determines the class of the non-sampled pixels. The classification was performed based on the channels short-wave infrared (SWIR) 1, near-infrared (NIR), red, and the normalised difference vegetation index (NDVI). NDVI is commonly used in vegetation studies and mitigates shadow effects (Powell et al. 2010). The accuracy of the classification was assessed using the kappa index (Congalton \&

Table 1 Landuse classifications for the study area in Parana

\begin{tabular}{lcl}
\hline Class & Assigned colour & \multicolumn{1}{c}{ Description } \\
\hline Natural vegetation & Red & $\begin{array}{l}\text { Early- to late-successional native vegetation, including } \\
\text { shrub vegetation to mature forests }\end{array}$ \\
Planted forest & Green & $\begin{array}{l}\text { Plantations of broad-leaved and pine species } \\
\text { Tillage and pasture }\end{array}$ \\
Uncovered soil & Yellow & Agricultural crops in any growth stage \\
\hline
\end{tabular}


Green 2008), comparing about 20 objects by class to the ground truth data.

Two post-classification processes were carried out. The first was the application of a low-pass filter to reduce the 'salt-and-pepper' effect (Piazza et al. 2016). This step eliminated objects of a certain class composed of only one pixel--pixels are influenced by neighbouring pixels and objects with one pixel unit are likely to be unreliable. Our method therefore ensured that the smallest object had nine pixels, i.e. 0.81 ha $\left(9 \times 900 \mathrm{~m}^{2}\right)$. The second post-classification process consisted of creating a change-detection map for the natural vegetation class to estimate vegetation area gained (regenerated) and lost (deforested) to the other landuses between 1992 and 2017.

\section{RESULTS}

The accuracy of the image classification was satisfactory, obtaining kappa values of 0.81 and 0.83 for 1992 and 2017 respectively. By following the criteria defined in Landis and Koch (1977), these kappa values corresponded to an almost perfect agreement.

The results showed that in 1992 and 2017, natural vegetation coverage in the study area around the INF had the largest hectarage, followed by uncovered soil, tillage and pasture, and planted forest. Nevertheless, the study area underwent large landscape changes during that period. Overall, the area under natural vegetation decreased by $18.3 \%$ from 52,700 ha while tillage and pasture cover increased by $65.7 \%$ from 16,602 ha. The total area under uncovered soil increased very slightly ( $1.4 \%$ from 38,139 ha) and planted forest cover dropped $22.0 \%$ from 8312 ha.

Of the original 52,700 ha of natural vegetation cover, there was a loss of 20,139 ha $(38.2 \%)$ and gain of 10,477 ha through natural or humandriven regeneration. The decrease and increase respectively translated to a net vegetation cover loss of 9600 ha over that period. A closer look at the natural vegetation cover dynamics revealed that net conversion to uncovered soil represented the most significant loss of vegetation cover, i.e. 12,470 ha of natural vegetation were converted to uncovered soil while only 3756 ha of uncovered soil were returned to natural vegetation cover during that time. Conversions of natural vegetation cover to and from tillage and pasture (5746 and 4000 ha respectively) yielded a net conversion of 1746 ha into crop and pasture. On the other hand, there was a net gain of 797 ha from planted forest cover to natural vegetation cover. As much as 1923 ha of natural vegetation cover was cleared to plant forests but 2720 ha of planted forests returned to natural vegetation cover over the 25-year study period.

The regeneration of natural vegetation cover had no apparent pattern but the loss of natural vegetation cover was not uniformly distributed throughout the study area (Figures 2 and 3). There was a notable loss of natural vegetation cover to uncovered soil adjoining the buffer zone's south perimeter, and south-west of the buffer zone. Of note, within the buffer zone, east of the INF, natural vegetation cover had also been replaced by uncovered soil in 2017. The largely contiguous area of natural vegetation south of the buffer zone had by 2017 become visibly fragmented and interspersed with tillage and pasture. From the landuse maps, it was evident that large areas of uncovered soil had been converted to tillage and pasture over the 25-year period. West of the buffer zone, the small areas of tillage and pasture within natural vegetation cover had expanded by 2017 at the expense of natural vegetation cover. The areas representing Araucarias Biological Reserve and the Ecological Station of Fernandes Pinheiro showed the least change in natural vegetation cover over the study period.

\section{DISCUSSION}

The changes in natural vegetation cover in our study area of 115,573 ha during the 25 years from 1992 to 2017 reflect-to a degreelanduse changes in the larger state of Parana, which covers 19.9 million ha. The return of 10,477 ha of planted forest, uncovered soil and tillage and pasture to natural vegetation cover from 1992 to 2017 represented $9.1 \%$ of the study area. In comparison, the regeneration of 75,612 ha (1985-2015) reported for Parana (SOSMA 2017) represented only $0.4 \%$ of the state. Regeneration of natural vegetation cover both in our study area and statewide could be attributed at least in part to the national environmental policies outlined previously. The success shown under ICMS-E by the three CUs in our study area may explain the high conversion rate to natural vegetation cover from 1992 to 2017. On the other hand, the loss 


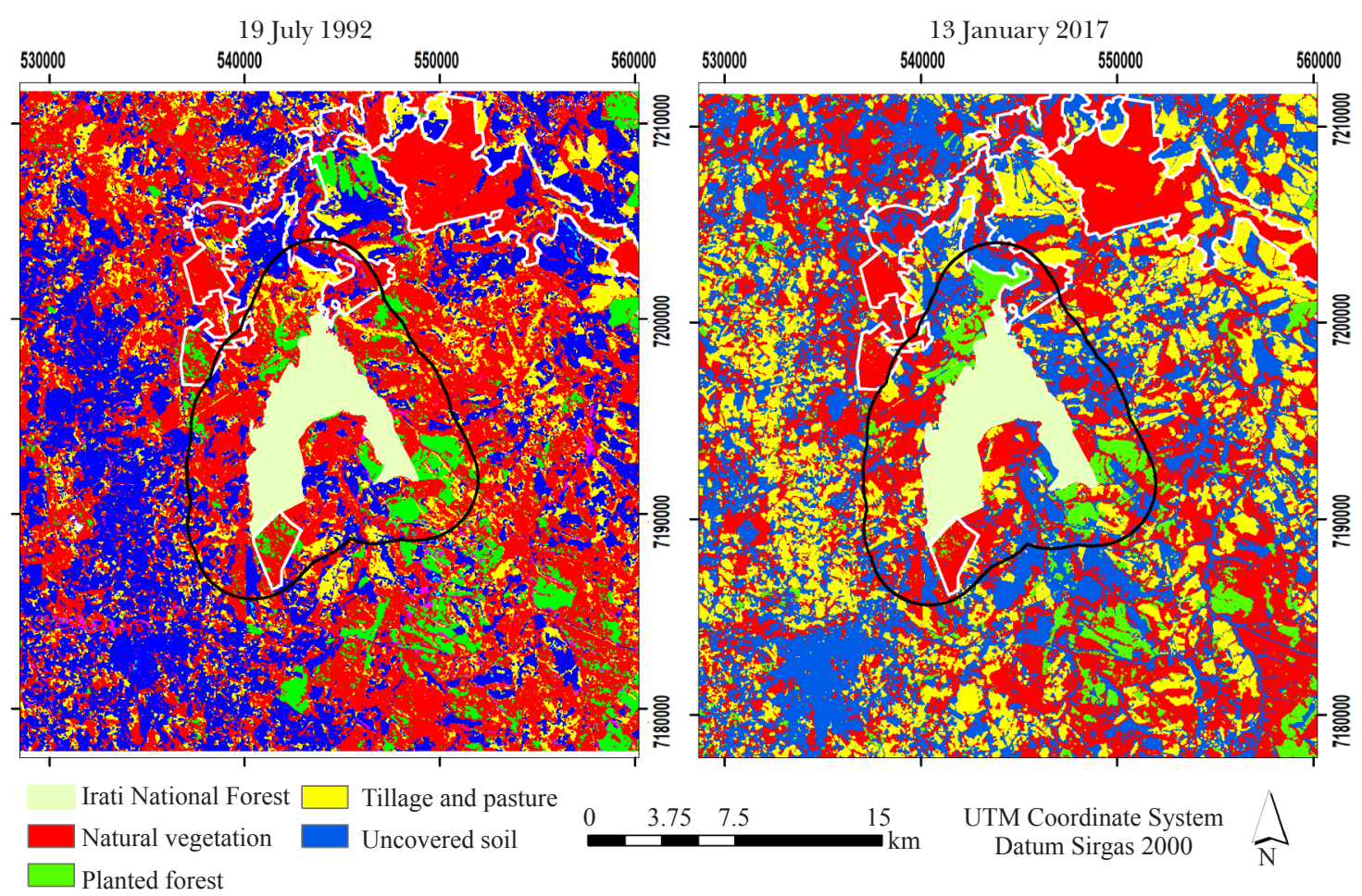

Figure 2 Landuse maps of the study area surrounding Irati National Forest (INF); buffer zone around INF represented by black solid line, white lines demarcate the Araucarias Biological Reserve (north) and Ecological Station of Fernandes Pinheiro (south)

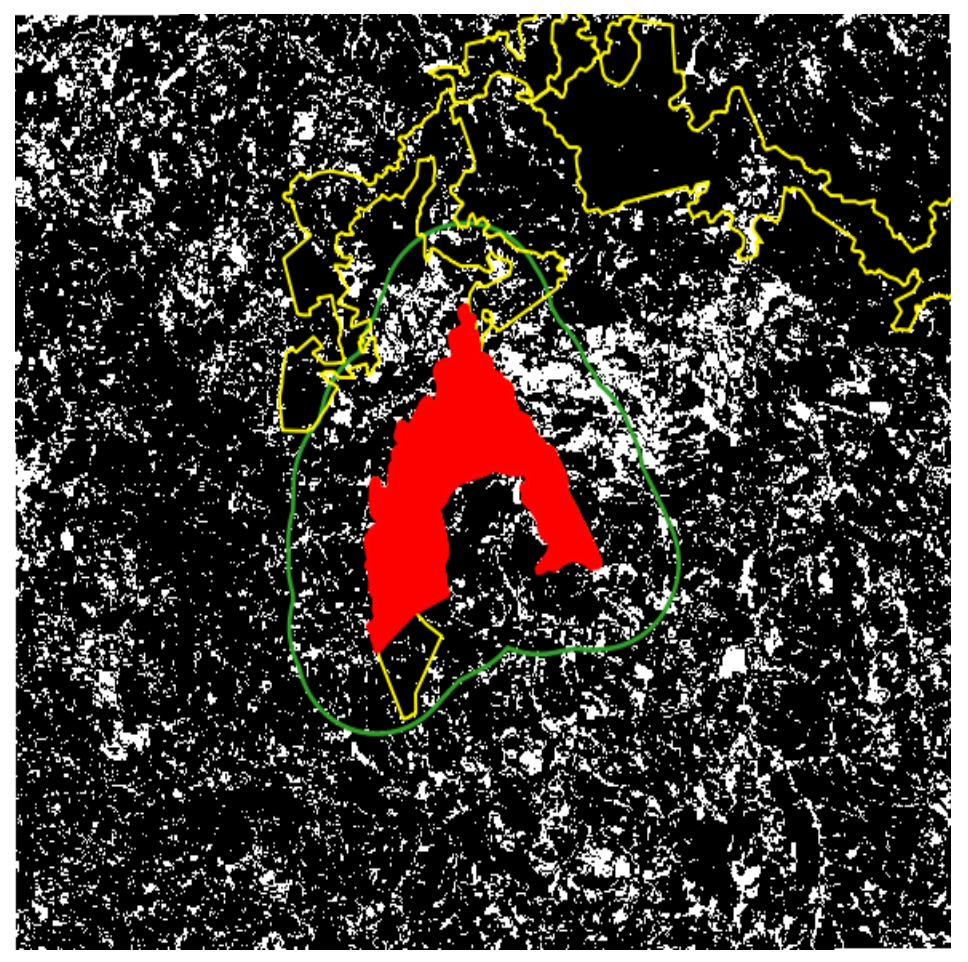

Figure 3 Natural vegetation cover changes in study area surrounding the Irati National Forest (INF) between 1992 and 2017; area shaded red is the INF, areas shaded black represent persistent natural vegetation, areas shaded white represent natural vegetation converted to other landuses, green line represents buffer zone boundary and yellow lines demarcate the Araucarias Biological Reserve (north) and Ecological Station of Fernandes Pinheiro (south) 
of natural vegetation cover of 20,139 ha $(17.4 \%$ of the study area) to other landuses (1992 to 2017) in our study area was high compared with the reported loss of natural vegetation cover statewide $(461,530$ ha or $2.3 \%$ of the state area) from 1985-2015 (SOSMA 2017).

The relatively smaller gains and losses in natural vegetation cover reported by SOSMA (2017) for Parana, compared with those for our study area, could be due to the following: (1) the SOSMA (2017) methodology only identified forest remnants larger than 3 ha whereas our study identified forest remnants as small as 0.81 ha. Parana has an extremely fragmented landscape where small forest fragments comprise the majority in the Atlantic Forest biome (David et al. 2017), therefore, our threshold may have captured a larger portion of regenerated areas than the methodology employed by SOSMA; and (2) the study area with its three CUs and high population density experienced more landuse changes than the state at large, which has a lower average population density and CUs spread out throughout the state.

\section{Drivers of deforestation}

The conversion of uncovered soil to tillage and pasture, and expansion of tillage and pasture into areas previously under natural vegetation cover indicated that the main driver of deforestation in our study area was agriculture, reflecting a nationwide trend-forest loss in Brazil has been overwhelmingly due to the expansion of agricultural activities and pasture areas. The dynamics of deforestation in Parana are not as complex as in the Amazon region where the main drivers are illegal logging, illegal land occupation ('grileiros'), and agricultural expansion for soybeans and beef production (Soares-Filho et al. 2010, Nepstad et al. 2014, Gibbs et al. 2015). According to the 2015 data from the Secretariat of Agriculture and Supply soybean cultivation appears to be driving deforestation in Parana, which is the largest producer of soybean in Brazil with 5 mil ha. In the four counties of Parana included in our study area, the area under soybean rose sharply from $\sim 10,000$ ha in 1992 to $\sim 125,000$ ha in 2017, supplanting corn as the most important field crop. The area under corn fell from 50,000 ha to 25,000 ha during the same period.
Logging, illegal and permitted, cannot be ruled out as a driver of deforestation in our study area, but its effect appears minor relative to soybean cultivation. While ABR and FPS, which are strict nature reserves, showed no loss of natural vegetation cover during the study period, the buffer zone area east of the INF lost natural vegetation cover to uncovered soil (possibly through harvesting logs).

\section{Effectiveness of conservation policies}

Monitoring and inspection of CUs and protected areas as provided for under ICMS-E may partly explain the persistence of natural vegetation cover in the ABR and FPS over the 25 years of our study. The establishment of such CUs in the Amazon has also been reported to successfully decrease the rate of deforestation in the last few decades (e.g. Ferreira et al. 2005, Ricketts et al. 2010, Nepstad et al. 2014). Conversely, deforestation doubled from 2008 to 2015 in CUs that were not adequately monitored and supervised (Araújo et al. 2017).

The noticeable conversion of native vegetation to pasture and tillage leaving a very fragmented landscape in the area east of the INF, within and beyond the buffer zone (Figure 2) indicates that the Native Vegetation Protection Law, which requires farmers to preserve $80 \%$ of the land in its native vegetation while cultivating $20 \%$, may not have been adhered to. While the law is clear, weakly specified property rights, poor enforcement due to insufficient government budgets, and strategic private land selling practices have made enforcement challenging (Marcussi 2016).

As conclusion, while there is evidence indicating that environmental policies have helped preserve natural vegetation cover and reduced deforestation over the long term, further research is needed to determine the degree to which these policies, individually and as a whole, contributed to the conservation of natural vegetation cover.

\section{REFERENCES}

Alvares CA, Stape JL, Sentelhas PC, Gonçalves JlM \& SPAROveK G. 2014. Köppen's climate classification map for Brazil. Meteorologische Zeitschrift 22: 711-728.

Araújo E, Barreto P, Baima S \& Gomes M. 2017. Unidades de Conservação Mais Desmatadas da Amazônia Legal (2012-2015). Belém: Imazon. 
COnAma (Conselho Nacional do Meio Ambiente). 1994. Resolução no 2, de 18 de Marşo de 1994. Diário Oficial da República Federativa do Brasil, Brasília.

Congalton RG \& Green K. 2008. Assessing the Accuracy of Remotely Sensed Data: Principles and Practices. Second edition. CRC Press, Boca Raton.

Crouzeilles R, Santiami E, Rosa M, Pugliese L et al. 2019. There is hope for achieving ambitious Atlantic Forest restoration commitments. Perspectives in Ecology and Conservation 17: 80-83.

David HC, Silva GF, Pezzopane JEM et al. 2017. Quantification and conservation status of forest fragments in part of Brazilian Atlantic Forest. African Journal of Agricultural Research 12: 740-749. https://doi.org/10.5897/ AJAR2016.12016.

Ferreira LV, VenticinQue E \& Almeida S. 2005. O desmatamento na Amazônia e a importância das áreas protegidas. Estudos Avançados 19: 157-166. http://dx.doi. org/10.1590/S0103-40142005000100010.

Gibbs HK, Rausch J, Munger J et al. 2015. Brazil's soy moratorium: supply-chain governance is needed to avoid deforestation. Science 347: 6220. doi: 10.1126/ science.aaa0181.

Landis J \& Koch G. 1977. The measurement of observer agreement for categorical data. Biometrics 33: 159174. doi: $10.2307 / 2529310$.

Laurance WF \& Vasconcelos HL. 2009. Consequências ecológicas da fragmentação florestal na Amazônia. Oecologia Brasiliensis 13: 434-451. https://doi. org/10.4257/oeco.2009.1303.03.

Marcussi JC. 2016. The Brazilian Amazon Timber Industry and the International Mechanisms of Timber Trade Control Combating Illegal Logging and Associated Trade. PhD dissertation, Pace University, New York.

Nepstad D, Mcgrath D, Stickler C et al. 2014. Slowing Amazon deforestation through public policy and interventions in beef and soy supply chains. Science 344: 1118-1123. doi: 10.1126/science.1248525.

Numata I, Silva SS, Cochrane MA \& D'oliveira MVN. 2017. Fire and edge effects in a fragmented tropical forest landscape in the southwestern Amazon. Forest Ecology and Management 401: 135-146. https://doi. org/10.1016/j.foreco.2017.07.010.

PAulo FLL \& CAmões PJS. 2018. Experiências internacionais no uso das transferências fiscais ecológicas para a conservação da biodiversidade. Revista de Políticas Públicas 22: 1073-1090. http://dx.doi. org/10.18764/2178-2865.v22n2p1073-1090.

Piazza GA, Vibrans AC, Liesenberg V \& Refosco JC. 2016. Object-oriented and pixel-based classification approaches to classify tropical successional stages using airborne high-spatial resolution images.
GIScience E Remote Sensing 53: 206-226. https:/ / doi. org/10.1080/15481603.2015.1130589.

Ponzoni FJ, Shimabukuro YE \& Kuplich TM. 2012. Sensoriamento Remoto da Vegetação. Second edition. Oficina de textos, São Paulo.

Powell SL, Cohen WB, Healey SP et al. 2010. Quantification of live aboveground forest biomass dynamics with Landsat time-series and field inventory data: a comparison of empirical modeling approaches. Remote Sensing of Environment 114: 1053-1068. https://doi.org/10.1016/j.rse.2009.12.018.

Richards JA. 1999. Remote Sensing Digital Image Analysis: An Introduction. Springer-Verlag, Berlin.

Ricketts TH, Soares-Filho B, Fonseca GAB et al. 2010. Indigenous lands, protected areas, and slowing climate change. Plos Biology 8: e1000331. https:// doi.org/10.1371/journal.pbio.1000331.

Ring I, Drechsler M, Van Teeffelen AJA, Irawan S \& Venter O. 2010. Biodiversity conservation and climate mitigation: what role can economic instruments play? Current Opinion in Environmental Sustainability 2: 50-58. https://doi.org/10.1016/j. cosust.2010.02.004.

Rode R, Figueiredo Filho A, Machado SA \& Galvão F. 2010. Análise do padrão espacial de espécies e de grupos florísticos estabelecidos em um povoamento de Araucaria angustifolia e em uma Floresta Ombrófila Mista no centro-sul do Parana. Revista Floresta 40: 255-268. http://dx.doi.org/10.5380/ rf.v40i2.17821.

Rode R, Figueiredo Filho A, Machado SA \& Galvão F. 2011. Grupos florísticos e espécies discriminantes em povoamento de Araucaria angustifolia e uma Floresta Ombrófila Mista. Revista Árvore 35: 319-327. http:/ / dx.doi.org/10.1590/S0100-67622011000200016.

Sauquet A, Marchand S \& Féres JG. 2014. Protected areas, local governments, and strategic interactions: the case of the ICMS-Ecológico in the Brazilian state of Parana. Ecological Economics 107: 249-258. https:/ / doi.org/10.1016/j.ecolecon.2014.09.008.

Soares-Filho B, Moutinho P, Nepstad D et al. 2010. Role of Brazilian Amazon protected areas in climate change mitigation. PNAS 107: 10821-10826, https://doi. org/10.1073/pnas.0913048107.

SOSMA. 2017. Relatório Anual de Atividades 2017. Fundação SOS Mata Atlântica, Sao Paolo. https:/ / www.sosma.org.br/wp-content/uploads/2018/10/ AF_RA_SOSMA_2017_web.pdf.

Tetto AF, Batista AC \& Soares RV. 2012. Zoneamento de risco de incêndios florestais para a Floresta Nacional de Irati, Estado do Parana, Brasil. Scientia Forestalis 40: 259-265. 